\title{
OBSERVATIONS OF CONTINUOUS INSTABILITY FOR SCAR INLET ICE SHELF, ANTARCTIC PENINSULA
}

\author{
Y. Li ${ }^{1,2}$, G. Qiao ${ }^{1,2} *$, X. Yuan ${ }^{1,2}$ \\ ${ }^{1}$ Centre for Spatial Information Science and Sustainable Development Applications, Tongji University, 1239 Siping Road, Shanghai \\ 200092, China - yanjunli_1995@outlook.com; (qiaogang, 1996yuanxiaohan) @ tongji.edu.cn \\ ${ }^{2}$ College of Surveying and Geo-Informatics, Tongji University, 1239 Siping Road, Shanghai, China
}

\section{Commission TCIII, WG III/9}

KEY WORDS: Scar Inlet Ice Shelf, Ice Front Position, Ice Velocity, Surface Features, Instability, Antarctica.

\begin{abstract}
:
Observation of the evolving instability of ice shelves plays a very important role in global change research. Following the suddenly large-scale collapse of the Larsen B Ice Shelf in the Antarctic Peninsula in 2002, the evolving instability for its remnant, the Scar Inlet Ice Shelf, began to be increasingly studied to provide a deeper understanding of the disintegration of the Larsen B Ice Shelf in 2002 and also provide a chance for studying the response of ice shelves to the large-scale collapse events. In this study, based on sequential Landsat images spanning 2005-2020, we produced detailed maps of the ice velocity fields for the Scar Inlet Ice Shelf. The results indicate that the ice velocities for the Scar Inlet Ice Shelf region have substantially increased since 2005, the maximum ice velocity reached more than $900 \mathrm{~m} / \mathrm{y}$ in the ice shelf front. Surface rifts have also substantially increased in both length and width and are moving seawards. The ice front position of the Scar Inlet Ice Shelf is relatively stable in 2008-2010 and then steadily advancing after 2010. The acceleration of ice velocities, the dynamic change of the ice front, the increase of major surface rifts and the newly added rifts in the central part of the ice shelf, and the heavily enhanced surface crevasses are all revealing the evolving instability of the Scar Inlet Ice Shelf.
\end{abstract}

\section{INTRODUCTION}

Antarctica, on average, is the coldest, driest, and windiest continent, and has the highest average elevation of all the continents, is currently the largest ice sheet in the world, with about $90 \%$ of the global ice mass. Ice mass loss from the whole ice sheet and its marine-based parts is a major contributor to global warming and sea level rise (Shepherd et al., 2012; Rignot et al., 2019). The Intergovernmental Panel on Climate Change (IPCC) reported that the global sea-level rise from the 1950s levels would likely be within $0.61-1.10 \mathrm{~m}$ if warming exceeds $4^{\circ} \mathrm{C}$ by 2100 , the uncertainty of the global sea level rise at the end of this century especially depends on the Antarctic ice sheet (IPCC, 2019). The two primary processes that account for the ice mass loss are basal melting and iceberg calving (Depoorter et al., 2013; Rignot et al., 2013). Iceberg disintegration can almost immediately cause the ice shelf to import a large amount of ice mass into the ocean, even tiny changes in the frequency or pattern of the calving events will have a huge impact on the ice mass budget (Rignot et al., 2013; Liu et al., 2015; Walker and Gardner, 2019).

Larsen ice shelves are located in the Antarctic Peninsula, northwest of the Weddell Sea, and include three different areas, Larsen A, Larsen B, and Larsen C. There have been two largescale ice shelf collapse events in the Antarctic Peninsula. Among them, the smallest one is Larsen A collapsed about $1,600 \mathrm{~km}^{2}$ in 1995 (Rott et al., 1996, 1998). During February-March 2002, the northern section of the Larsen B Ice Shelf disintegrated in less than 6 weeks, $2,300 \mathrm{~km}^{2}$ of the ice shelf broke up into many small floating icebergs (Rack and Rott, 2004; Glasser and Scambos, 2008; Bassis, 2020). After that, the remnant Larsen B Ice Shelf, namely the Scar Inlet Ice Shelf has experienced two calving events in early 2006 and late 2007/early 2008 (Khazendar et al., 2015). The collapse of the Larsen B Ice Shelf has led to a decrease in backstress, a flow acceleration of the ice shelf and its tributaries, a decline in surface elevation, a retreat in ice front position, and a substantial increase in both scope and scale of the rifts and crevasses (Glasser and Scambos, 2008; Shepherd et al., 2010; Shuman et al., 2011; De Rydt et al., 2015; Khazendar et al., 2015; Wuite et al., 2015; Chen et al., 2018; Rott et al., 2018; Qiao et al., 2020). Ice shelves around the Larsen A and Larsen B ice shelves such as the Larsen C Ice Shelf and the Seal Nunataks Ice Shelf are also affected by these calving events (Shuman et al., 2016; Han et al., 2019). The analysis of the incurred ice shelf disintegrations and the instability of the ice shelf after calving can help us predict the next ice shelf to collapse, which is of great significance for understanding the contribution of ice shelf disintegrations on the discharge of grounded ice into the ocean (Bassis, 2020).

In this paper, we provide a continuum observation for the previous work (Qiao et al., 2020), the latest dynamic and structural behaviours of Scar Inlet Ice Shelf were investigated, including the ice front positions, rifts propagation, and ice velocities based on sequential Landsat satellite images. The longterm observations of the changes in the frontal position and surface features and ice velocities in time and space up to 2020, all of these indicate the evolving instability of the Scar Inlet Ice Shelf.

\footnotetext{
* Corresponding author
} 


\section{DATA AND METHODS}

\subsection{Study Area and Data}

Scar Inlet Ice Shelf is located between the Weddell Sea and the region from northern Robertson Island to southern Jason Peninsula, is the remnant part of the Larsen B Ice Shelf after its calving event in 2002. After that, the two rift calving events in 2006 and 2008 makes the Scar Inlet Ice Shelf experience substantial losses of ice area, approximately $650 \mathrm{~km}^{2}$ and 140 $\mathrm{km}^{2}$, respectively (Scambos et al., 2008; Qiao et al., 2020). Figure 1 shows the Landsat image of the Scar Inlet Ice Shelf and its tributary glaciers captured on 18 December 2002. The rifts, ice front positions, the stagnant region, the MEaSUREs grounding line (MEaSUREs GL 1999) are presented in Figure 1.

In this study, 21 sequential Landsat satellite images including Landsat 7 enhanced thematic mapper plus (ETM+) and the Landsat 8 operational land imager (OLI) with band 8 (15m), spanning 2005-2020 are used to reconstruct the annual ice velocity fields and the evolution of rifts of the Scar Inlet Ice Shelf. All the images were carefully selected and try to have no or few clouds. The data-gap regions in Landsat 7 ETM+ images are filled by ENVI image analysis software (Warner and Roberts, 2013), and all the Landsat images are enhanced using low-pass and high-pass filters (Schowengerdt et al., 2006). The making earth system data records for use in research environments (MEaSUREs) grounding line product with the highest accuracy at about $\pm 100 \mathrm{~m}$ is used for subsequent analyses (Rignot et al., 2011).

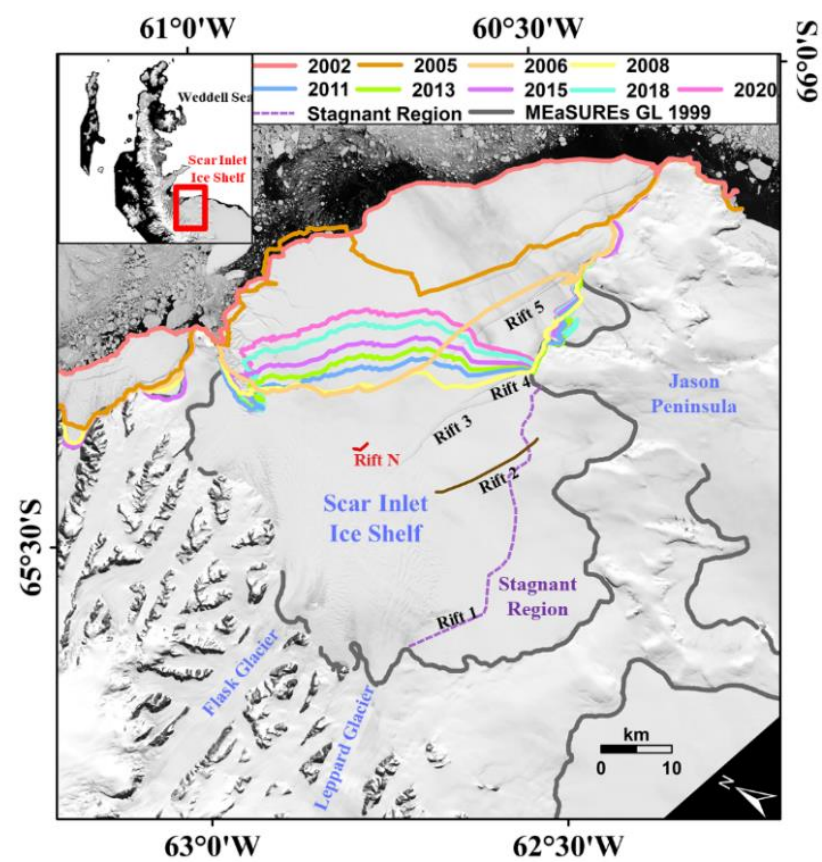

Figure 1. Study area of the Scar Inlet Ice Shelf and its tributary glaciers on 18 December 2002.

\subsection{Methods}

We use the IMCORR image correlation software (Release 1.1, http://nsidc.org/data/velmap/imcorr.html, Scambos et al., 1992) to map the ice velocity fields based on the feature-tracking technology. The time interval between the two images is approximately 1 year, the reference window, search window, and grid space sizes to be $64 \times 64,192 \times 192$, and $10 \times 10$ pixels, respectively. The location of the center of the reference chip, the total displacement in pixels, the strength of the correlation and resulting flag, the displacement to best match within the search chip, and the estimated error are the main output parameters of IMCORR. The strength of the correlation (S) presents the degree of correlation between the matched features of two images, which is defined as follows:

$$
\mathrm{S}=\frac{\left(R_{\text {max }}-R_{\text {mean }}\right)}{R_{\text {std }}}+\frac{\left(R_{\max }-R_{\max 2}\right)}{R_{\text {std }}}+0.2 *\left(N_{\max 2}-1\right)
$$

where $S=$ the strength of the correlation

$R_{\max }=$ the peak correlation value

$R_{\text {mean }}=$ the mean value of the correlation coefficient

$R_{s t d}=$ the standard deviation of the correlation coefficient

$R_{\max 2}=$ the highest value more than 3 pixels away from the peak

$N_{\max 2}=$ the number of "large" values more than 3 pixels away from the peak.

In addition, we manually digitized the positions of the ice front, the position accuracy of the Scar Inlet Ice Shelf front sequences was estimated to be approximately $15 \mathrm{~m}$ or within 1 pixel. Furthermore, we visually interpreted the length and width changes in the major rifts on the surface of the Scar Inlet Ice Shelf and analyze the dynamics of the major rift based on sequential Landsat images by ArcMap geographical information system (GIS) software (version 10.5). The accuracy was estimated to be approximately $15 \mathrm{~m}$ or within 1 pixel.

\section{RESULIS}

\subsection{Observation of the Scar Inlet Ice Shelf Ice Front Position Changes}

After the collapse in 2002, the ice front of the Scar Inlet Ice Shelf retreated about $16 \mathrm{~km}$ and reached the ice front position in 2005 . In February 2006, the second major calving event of the Scar Inlet Ice Shelf occurred along Rift 5, resulting in an approximately $20 \mathrm{~km}$ retreat. Then, in February 2008, the third major calving event along Rift 4 caused the eastern part of the ice front position to recede by about $11 \mathrm{~km}$ (Shuman et al., 2011; Qiao et al., 2020). Since then, the Scar Inlet Ice Shelf ice front position has shown a relatively stable trend in 2008-2010. From 2010 to 2020, the Scar Inlet Ice Shelf ice front position showed a steady advancement with a mean rate of approximately $1 \mathrm{~km} / \mathrm{y}$.

\subsection{Evolution of Rifts in the Scar Inlet Ice Shelf}

Qiao et al. (2020) analyzed the annual change of five major rifts in the Scar Inlet Ice Shelf from 2005 to 2018. The widths are increased the lengths are stable or increased for all five rifts from January 2005 to September 2018. Here, we extended this longterm observation for Rift 1- Rift 3 to November 2020 since the two calving events in 2006 and 2008 caused Rift 5 and Rift 4 to disappear respectively. Table 1 showed the lengths and maximum widths for the three major rifts in the Scar Inlet Ice Shelf from 2005 to 2020, it can be seen that the widths of all three rifts are increased, where the increase rate of Rift 1 and Rift 3 is relatively significant, about $0.16 \mathrm{~km} / \mathrm{y}$, is twice as much as the increase rate of Rift 2. The increase rate of the length of Rift 2 is $0.88 \mathrm{~km} / \mathrm{y}$, which is the largest among the three rifts. Now, Rift 3 is nearest to the ice shelf front and continued to widen, which may make it be the next calving margin. 


\begin{tabular}{|c|cc|cc|cc|}
\hline \multirow{2}{*}{ Date } & \multicolumn{2}{|c|}{ Rift 1 } & \multicolumn{2}{c|}{ Rift 2 } & \multicolumn{2}{c|}{ Rift 3 } \\
& Length $(\mathrm{km})$ & Width $(\mathrm{km})$ & Length $(\mathrm{km})$ & Width $(\mathrm{km})$ & Length $(\mathrm{km})$ & Width $(\mathrm{km})$ \\
\hline 8 Jan. 2005 & 18.8 & 0.3 & - & - & 20.3 & 0.4 \\
27 Nov. 2012 & 24.4 & 2.5 & 14.9 & 0.1 & 20.7 & 2.8 \\
24 Sep. 2018 & 30.3 & 3.5 & 18.4 & 1.1 & 19.5 & 3.5 \\
13 Oct. 2019 & 31.1 & 3.6 & 18.4 & 1.4 & 18.6 & 3.7 \\
9 Nov. 2020 & 32.4 & 3.7 & 18.5 & 1.6 & 18.5 & 3.7 \\
\hline
\end{tabular}

Table 1. The lengths and maximum widths for the three major rifts in the Scar Inlet Ice Shelf from 2005 to 2020

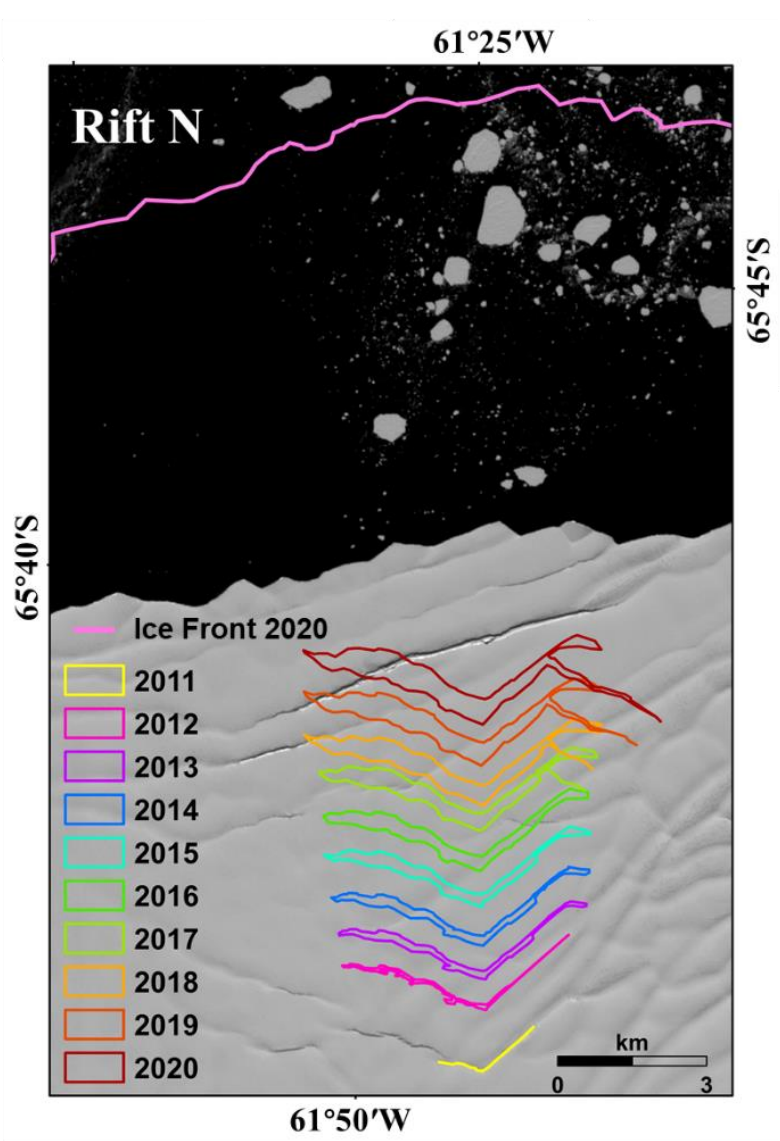

Figure 2. Evolution for Rift N (Figure 1) in the Scar Inlet Ice Shelf from 2011 to 2020. The background image is Landsat image acquired on 26 February 2011.
Based on these sequential Landsat images from 2005 to 2020, we also found a new rift that is slowly evolving (Rift $\mathrm{N}$ in Figure 1) which is located in the central part of the SIIS. Figure 2 showed the evolution for Rift N ((Figure 1) from February 2011 to November 2020. This rift appeared in the 2010 image for the first time, but due to the cloud distribution in the image, we could not get its actual shape accurately in 2010 . It can be seen that its length and width are both increase from 2011 to 2020. At the same time, it is moving towards the sea along with the ice flow.

\subsection{Reconstruction of Ice Velocity Filed}

In this study, we extended the annual ice velocity fields of the Scar Inlet Ice Shelf from 2018 to 2020 (Figure 3 showed 9 periods of ice velocity maps), all of these ice velocity maps were smoothed by using the local mean filter. In general, the ice velocity of the Scar Inlet Ice Shelf showed an increasing trend from 2005 to 2020 . Spatially, ice velocity increased from about $600 \mathrm{~m} / \mathrm{y}$ and $500 \mathrm{~m} / \mathrm{y}$ at the Flask and Leppard Glaciers respectively, reached more than $900 \mathrm{~m} / \mathrm{y}$ at the ice front. Ice velocity in the central part of the ice front is higher than the flanks of the Scar Inlet Ice Shelf. It can also be seen that ice flows faster from the Flask Glacier than the Leppard Glacier. In addition, ice velocity in the Stagnant Region was very stable and almost unchanged in 2005-2020.

In order to estimate the change in this long-term ice velocity field, we analyze the evolution at a Check Point (Black Cross point in Figure 3), which was located near the ice front in 2006 (Khazendar et al., 2015; Qiao et al., 2020). Figure 4 showed the evolution of the ice velocity at the Check Point from 2005 to 2020. Overall, the ice velocity of the Check Point increased from 627 $\mathrm{m} / \mathrm{y}$ in 2005 to $799 \mathrm{~m} /$ year in 2020 , showing a $27.4 \%$ increase. The calving events in 2006 and 2008 resulted in an approximately $50 \mathrm{~m} / \mathrm{y}$ decrease in ice velocities. From 2008 to 2013, the ice velocity of the Check Point increased by about $187 \mathrm{~m} / \mathrm{y}$. After 2013, the ice velocities at the Check Point exhibiting a stable trend. 

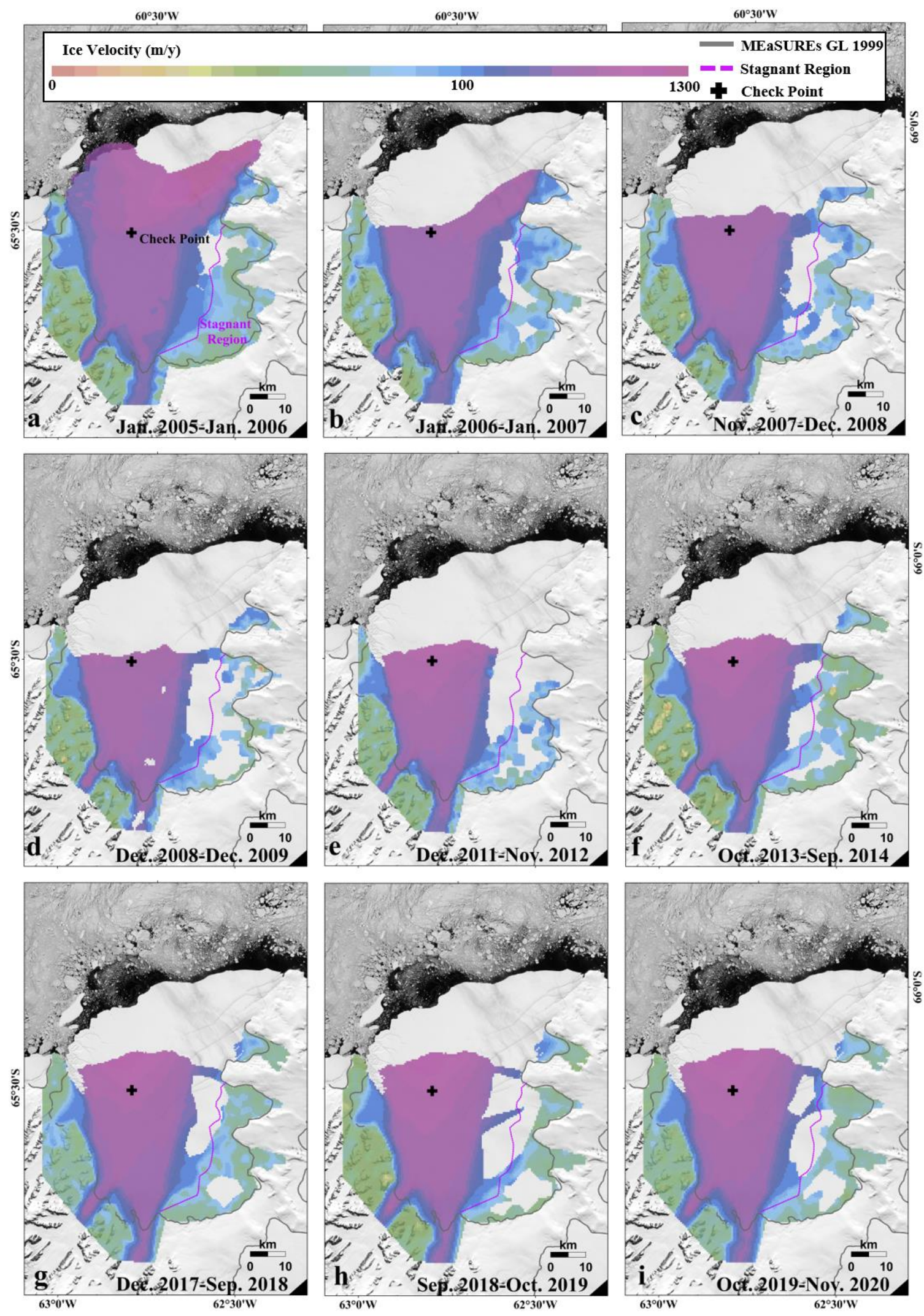

Figure 3. Ice velocity maps of the Scar Inlet Ice Shelf from 2005 to 2020: (a) Jan. 2005-Jan. 2006, (b) Jan. 2006-Jan. 2007, (c) Nov. 2007-Dec. 2008, (d) Dec. 2008-Dec. 2009, (e) Dec. 2011-Nov. 2012, (f) Oct. 2013-Sep. 2014, (g) Dec. 2017-Sep. 2018, (h) Sep. 2018-Oct. 2019, (i) Oct. 2019-Nov. 2020. The background image is Landsat image acquired on 18 December 2002. 


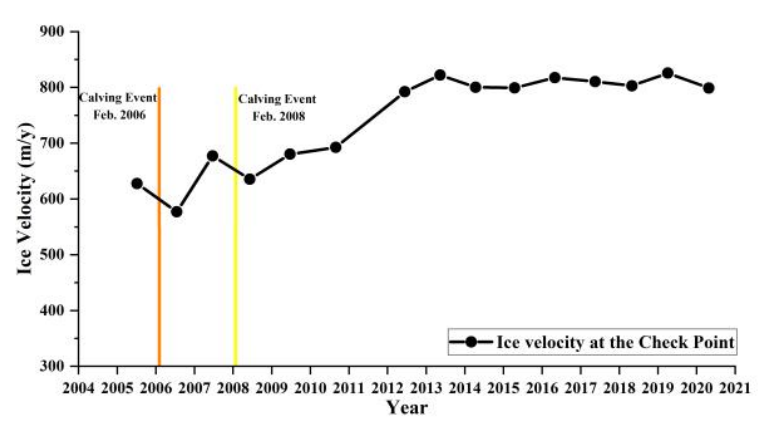

Figure 4. Evolution of the annual ice velocity at the Check Point (Figure 3) from 2005 to 2020.

\section{CONCLUSIONS}

In this study, we analyzed the long-term dynamics of ice front positions, major rifts' propagation and ice velocity fields of the Scar Inlet Ice Shelf based on sequential Landsat satellite images spanning 2005-2020, to reveal its evolving instability.

The results reflect that the ice velocities for the Scar Inlet Ice Shelf region have continuum increased since 2005, reaching a maximum value of more than $900 \mathrm{~m} / \mathrm{y}$ along the ice front. The two calving events in 2006 and 2008 are accompanied by a first increase in ice velocity and then a sharp decrease. Then, ice velocities increased from 2008 to 2013 but remained relatively stable thereafter. The Scar Inlet Ice Shelf ice front position is relatively stable in 2008-2010 and then has been steadily advancing until 2020. Both the length and width of major rifts on the ice surface substantially increased. The acceleration of ice flows, the rapid growth of major surface rifts, the dynamic position of the ice front, plus the large new rifts in the central part of the Scar Inlet Ice Shelf and the heavily enhanced surface crevasses are all indicators that reveal the evolving instability of the Scar Inlet Ice Shelf.

\section{ACKNOWLEDGEMENTS}

This research was supported by the National Key Research and Development Program of China (2017YFA0603102 and 2017YFB0503502), the National Science Foundation of China (41771471, 41941006, and 42011530088).

We would like to thank the United States Geological Survey (USGS) for providing the Landsat images used in this study.

\section{REFERENCES}

Bassis, J. N., 2020: Crevasse analysis reveals vulnerability of ice shelves to global warming. Nature 584, 527-528.

Chen, J., Ke, C. Q., Zhou, X., 2018: Variations in the extent and elevation of the Larsen A and B ice shelves, Antarctica, derived from multiple datasets. Journal of Applied Remote Sensing 12(4), 046019.

Depoorter, M. A., Bamber, J. L., Griggs, J. A., Lenaerts, J. T., Ligtenberg, S. R., van den Broeke, M. R., Moholdt, G., 2013: Calving fluxes and basal melt rates of Antarctic ice shelves. Nature 502(7469), 89-92.

De Rydt, J., Gudmundsson, G. H., Rott, H., Bamber, J. L., 2015: Modeling the instantaneous response of glaciers after the collapse of the Larsen B Ice Shelf. Geophysical Research Letters 42(13), 5355-5363.

Glasser N. F., Scambos T. A., 2008: A structural glaciological analysis of the 2002 Larsen B Ice Shelf collapse. Journal of Glaciology 54(184), 3-16.

Han, H., Lee, S., Kim, J. I., Kim, S. H., Kim, H. C., 2019: Changes in a giant iceberg created from the collapse of the Larsen $\mathrm{C}$ ice shelf, Antarctic Peninsula, derived from Sentinel-1 and CryoSat-2 data. Remote Sensing 11(4), 404.

IPCC, 2019: Summary for Policymakers. In: IPCC Special Report on the Ocean and Cryosphere in a Changing Climate $[\mathrm{H}$.O. Pörtner, D.C. Roberts, V. Masson-Delmotte, P. Zhai, M. Tignor, E. Poloczanska, K. Mintenbeck, A. Alegría, M. Nicolai, A. Okem, J. Petzold, B. Rama, N.M. Weyer (eds.)]. In press.

Khazendar, A., Borstad, C.P., Scheuchl, B., Rignot, E., Seroussi, H., 2015: The evolving instability of the remnant Larsen B ice shelf and its tributary glaciers. Earth and Planetary Science Letters 419, 199-210.

Liu, Y., Moore, J. C., Cheng, X., Gladstone, R. M., Bassis, J. N., Liu, H., Wen, J., Hui, F., 2015: Ocean-driven thinning enhances iceberg calving and retreat of Antarctic ice shelves. Proceedings of the National Academy of Sciences 112(11), 3263-3268.

Qiao, G., Li, Y., Guo, S., Ye, W. 2020: Evolving Instability of the Scar Inlet Ice Shelf based on Sequential Landsat Images Spanning 2005-2018. Remote Sensing 12(1), 36.

Rack, W., Rott, H., 2004: Pattern of retreat and disintegration of the Larsen B ice shelf, Antarctic Peninsula. Annals of glaciology $39,505-510$.

Rignot, E., Mouginot, J., Scheuchl, B., 2011: Antarctic grounding line mapping from differential satellite radar interferometry. Geophysical Research Letters 38(10).

Rignot, E., Jacobs, S., Mouginot, J., Scheuchl, B., 2013: Ice-shelf melting around Antarctica. Science 341(6143), 266-270.

Rignot, E., Mouginot, J., Scheuchl, B., Van den Broeke, M., Van Wessem, M., Morlighem, M., 2019: Four decades of Antarctic Ice Sheet mass balance from 1979-2017. Proceedings of the National Academy of Sciences 116, 1095-1103.

Rott, H., Skvarca, P., Nagler, T., 1996: Rapid collapse of northern Larsen ice shelf, Antarctica. Science 271(5250), 788792.

Rott, H., Rack, W., Nagler, T., Skvarca, P., 1998: Climatically induced retreat and collapse of northern Larsen Ice Shelf, Antarctic Peninsula. Annals of Glaciology 27, 86-92.

Rott, H., Abdel Jaber, W., Wuite, J., Scheiblauer, S., Floricioiu, D., Wessem, J. M. V., Nagler, T., Miranda, N., van den Broeke, M. R., 2018: Changing pattern of ice flow and mass balance for glaciers discharging into the Larsen A and B embayments, Antarctic Peninsula, 2011 to 2016. The Cryosphere 12(4), 12731291.

Scambos, T.A., Dutkiewicz, M.J., Wilson, J.C., Bindschadler, R.A., 1992: Application of image cross-correlation to the measurement of glacier velocity using satellite image data. Remote sensing of environment $42,177-186$. 
Scambos, T., Ross, R., Bauer, R., Yermolin, Y., Skvarca, P., Long, D., Bohlander, J., Haran, T., 2008: Calving and ice-shelf break-up processes investigated by proxy: Antarctic tabular iceberg evolution during northward drift. Journal of Glaciology $54,579-591$.

Schowengerdt, R.A., 2006: Remote Sensing: Models and Methods for Image Processing. Elsevier: Amsterdam.

Shepherd, A., Wingham, D., Wallis, D., Giles, K., Laxon, S., Sundal, A.V., 2010: Recent loss of floating ice and the consequent sea level contribution. Geophysical Research Letters 37(13).

Shepherd, A., Ivins, E.R., Barletta, V.R., Bentley, M.J., Bettadpur, S., Briggs, K.H., Bromwich, D.H., Forsberg, R., Galin, N., Horwath, M., Jacobs, S., Joughin, I., King, M.A., Jan, T.M.L., Li, J., Stefan, R.M.L., Luckman, A., Luthcke, S.B., McMillan, M., Meister, R., Milne, G., Mouginot, J., Muir, A., Nicolas, J.P., Paden, J., Payne, A.J., Pritchard, H., Rignot, E., Rott, H., Sørensen, L.S., Scambos, T.A., Scheuchl, B., Ernst, J.O.S., Smith B., Sundal, A.V., Jan, H.V.A., Willem, J.V.D.B., Michiel, R.V.D.B., Vaughan, D.G., Velicogna, I., Wahr, J., Whitehouse, P.L., Wingham, D.J., Yi, D., Young, D., Zwally, H.J., 2012: A reconciled estimate of Ice-Sheet mass balance. Science 338 (6111), 1183-1189.

Shuman, C.A., Berthier, E., Scambos, T.A, 2011: 2001-2009 elevation and mass losses in the Larsen A and B embayments, Antarctic Peninsula. Journal of Glaciology 57, 737-754.

Shuman, C., Scambos, T., Berthier, E., 2016: Ice loss processes in the Seal Nunataks ice shelf region from satellite altimetry and imagery. Annals of Glaciology 57, 94-104.

Walker, C. C., Gardner, A. S., 2019: Evolution of ice shelf rifts: Implications for formation mechanics and morphological controls. Earth and Planetary Science Letters 526, 115764.

Warner, R. C., Roberts, J. L., 2013: Pine Island Glacier (Antarctica) velocities from Landsat7 images between 2001 and 2011: FFT-based image correlation for images with data gaps. Journal of Glaciology 59(215), 571-582.

Wuite, J., Rott, H., Hetzenecker, M., Floricioiu, D., De Rydt, J., Gudmundsson, G.H., Nagler, T., Kern, M., 2015: Evolution of surface velocities and ice discharge of Larsen B outlet glaciers from 1995 to 2013. The Cryosphere 9, 957-969. 